\title{
Effects of hyperaccumulator plant straw on biomass and cadmium accumulation of lettuce
}

\author{
Le Liang ${ }^{1}$, Ran Zhang ${ }^{2}$, Yan Zhao'2, Ying Zhu², Qiaoman $\mathrm{Ao}^{2}$ and Yi Tang ${ }^{1 *}$ \\ ${ }^{1}$ Institute of Pomology and Olericulture, Sichuan Agricultural University, Chengdu, Sichuan, 611130, China \\ ${ }^{2}$ College of Horticulture, Sichuan Agricultural University, Chengdu, Sichuan, 611130, China
}

\begin{abstract}
To study the effects of hyper-accumulator plant straw on the biomass and cadmium (Cd) accumulation of lettuce (Lactuca sativa), the pot experiments were conducted to study the effects of straw application of three hyper-accumulator plants (Solanum nigrum, Bidens pilosa and Galinsoga parviflora) on the biomass and $\mathrm{Cd}$ accumulation of lettuce under $\mathrm{Cd}$ stress. The results show that: compared with no straw application, the biomass of lettuce was increased after applying three kinds of hyper-accumulator plant straw: S. nigrum, B. pilosa and G. parviflora, Cd content in the above ground part of lettuce was increased by $4.46 \%, 1.20 \%$ and $0.63 \%$ respectively, compared with that of non-application, and Cd content in the root of lettuce was decreased. The application of three kinds of hyperaccumulator plant straw promoted the growth of lettuce and increased Cd uptake by lettuce of aerial part.
\end{abstract}

\section{Introduction}

Straw returning is an effective ecological agricultural measure, and straw will release organic matter, nitrogen, phosphorus, potassium and other nutrients after decomposition, and can improve the physical and chemical properties of soil, enhance the activity of biological and most enzymes, and promote the growth and development of stubble crops and increase yield [1-2]. Because of various industrial activities, cadmium (Cd) accumulates within the soil and has the ability to remain the food chain for extended periods of time, poses a significant health risk to humans [3]. Lettuce (Lactuca sativa) is an important leafy vegetable crop that produces great wealth, which typically accumulate significantly more $\mathrm{Cd}$ in their edible parts than other vegetables [4-5]. Solanum nigrum, Bidens pilosa and Galinsoga parviflora are common hyperaccumulator plants in farmland, which have the characteristics of wide source, convenient collection, large number and wide distribution. This experiment explored the effects of application of hyperaccumulator plant straw on the growth and $\mathrm{Cd}$ accumulation of lettuce under $\mathrm{Cd}$ pollution conditions, and provided reference for the safe production of lettuce in the future.

\section{Materials and Methods}

\subsection{Experiment Materials}

In June 2015, three kinds of Cd hyperaccumulator plants were collected from the surrounding farmland (not contaminated by heavy metals) in the Sichuan
Agriculture University: S. nigrum, B. pilosa and $G$. parviflora, after removing the seeds, they are washed with distilled water. After 15 minutes of killing fresh at $105{ }^{\circ} \mathrm{C}$, they are dried to constant weight at $75^{\circ} \mathrm{C}$. Cutting the dried straw into about $1 \mathrm{~cm}$ segments and set aside.

Lettuce is a common glass lettuce in Sichuan, it has high purity, good quality, good tolerance and resistance, and can be planted all year round and sustainable harvest for more than 50 days.

The tested soil was paddy soil, which was taken from farmland not polluted by heavy metals around Chengdu campus of Sichuan Agricultural University, and its basic physical and chemical properties are as follows: $\mathrm{pH} 6.36$, organic matter $18.10 \mathrm{~g} / \mathrm{kg}$, total nitrogen $1.04 \mathrm{~g} / \mathrm{kg}$, total phosphorus $1.36 \mathrm{~g} / \mathrm{kg}$, total potassium $20.78 \mathrm{~g} / \mathrm{kg}$, hydrolyzable nitrogen $43.90 \mathrm{mg} / \mathrm{k}$, available phosphorus $92.71 \mathrm{mg} / \mathrm{kg}$, available potassium $134.25 \mathrm{mg} / \mathrm{kg}$, available $\mathrm{Cd}$ not was detected. $\mathrm{CdCl}_{2} 2.5 \mathrm{H}_{2} \mathrm{O}$ analytical pure solution was added to the tested soil for heavy metal Cd.

\section{2 .Experiment Method}

In June 2015, the air-dried and crushed soil was sifted through 300 meshes and loaded into barrels, each containing $20 \mathrm{~kg}$. The $\mathrm{Cd}$ concentration was $10 \mathrm{mg} / \mathrm{kg}$ by adding analytical pure $\mathrm{CdCl}_{2} 2.5 \mathrm{H}_{2} \mathrm{O}$ solution [6], after 30 days of moist storage, all contaminated soils are fully blended and packed in a pot of $3 \mathrm{~kg}$ per pot.

Full lettuce seeds were select for disinfection, evenly spread them on wet gauze, put them into $20{ }^{\circ} \mathrm{C}$ light incubator for germination, and then sow them in a pot dish with nutritive soil to raise seedlings. After one week

\footnotetext{
*Corresponding author's e-mail: 95459425@qq.com
} 
of lettuce seedling raising, three kinds of hyperaccumulator plant straw were applied to the prepared Cd contaminated soil, $6 \mathrm{~g}$ per pot, and mixed evenly, with no straw as the control. The experiment was divided into four treatments: no straw, $S$. nigrum straw, $B$. pilosa straw and $G$. parviflora straw. After a week of balancing and watering, select healthy lettuce seedlings and transplant them into Cd-contaminated soil prepared with straw. Four plants were transplanted in each pot and nine pots were treated in each pot. After transplanting, the seedlings were placed in plastic greenhouse, and the soil moisture was maintained at about $80 \%$. After the lettuce grew $50 \mathrm{~d}$, the $\mathrm{Cd}$ content in lettuce plants was measured, the intact roots were removed, and the root and shoot were washed with tap water respectively, then rinsed with deionized water for 3 times, dried and weighed separately. Finally, the shoot and root were killed fresh at $110{ }^{\circ} \mathrm{C}$ for $15 \mathrm{~min}$, and dried at $75{ }^{\circ} \mathrm{C}$ to constant weight. The $\mathrm{Cd}$ content in root was measured after weighing.

\subsection{Statistical analyses}

All data are collated with Excel 2010 software; SPSS 20.0 was used for variance analysis and Duncan's new complex range method was used for multiple comparisons. Root-shoot ratio $=$ root dry weight $/$ shoot dry weight [7]; transport coefficient $=\mathrm{Cd}$ content in shoot/Cd content in root [8].

\section{Results}

\subsection{Effects of soil application of hyperaccumulator plant straw on biomass of lettuce}

Application of hyperaccumulator plant straw promoted the growth of lettuce, the fresh weight of shoot and root of lettuce was significantly higher than that of the control (Table 1). Compared with the control, the shoot fresh weight of lettuce with application $S$. nigrum straw, $B$. pilosa straw and $G$. parviflora straw increased by $18.11 \%(\mathrm{P}<0.05), 15.31 \%(\mathrm{P}<0.05)$ and $21.65 \%(\mathrm{P}<$ $0.05)$. The fresh root weight of lettuce in each treatment from high to low was as follows: $S$. nigrum straw $>G$. parviflora straw $>$ B. pilosa straw $>$ no straw. All treatments were significantly higher than the control, but there was no difference among the treatments. The shoot dry weight of lettuce treated with G. parviflora straw was significantly higher than that of the control, which was $16.82 \%$ higher than that of the control $(\mathrm{P}<0.05)$. Compared with the control, the dry weight of lettuce root increased by $62.50 \%(\mathrm{P}<0.05), 50.00 \%(\mathrm{P}<0.05)$ and $70.83 \%(\mathrm{P}<0.05)$ with the application of $S$. nigrum straw, B. pilosa straw and G. parviflora straw. The root-shoot ratio of lettuce with hyperaccumulate plant straw was higher than those without straw.

Table 1. Effects of hyperaccumulate plant straw on the biomass of lettuce

\begin{tabular}{cccccc}
\hline Plant straw & $\begin{array}{c}\text { Shoot fresh weight } \\
\text { (g/plant) }\end{array}$ & $\begin{array}{c}\text { Root fresh } \\
\text { weight }(\mathrm{g} / \text { plant })\end{array}$ & $\begin{array}{c}\text { Shoot dry weight } \\
\text { (g/plant) }\end{array}$ & $\begin{array}{c}\text { Root dry weight } \\
\text { (g/plant) }\end{array}$ & $\begin{array}{c}\text { Root shoot } \\
\text { ratio }\end{array}$ \\
\hline No straw & $59.13 \pm 2.10 \mathrm{~d}$ & $3.02 \pm 0.20 \mathrm{~b}$ & $2.20 \pm 0.14 \mathrm{~b}$ & $0.24 \pm 0.01 \mathrm{~b}$ & 0.11 \\
S. nigrum straw & $69.84 \pm 0.35 \mathrm{~b}$ & $4.58 \pm 0.21 \mathrm{a}$ & $2.42 \pm 0.07 \mathrm{~b}$ & $0.39 \pm 0.03 \mathrm{a}$ & 0.16 \\
B. pilosa straw & $68.18 \pm 2.74 \mathrm{c}$ & $4.42 \pm 0.45 \mathrm{a}$ & $2.24 \pm 0.14 \mathrm{~b}$ & $0.36 \pm 0.03 \mathrm{a}$ & 0.16 \\
G. parviflora straw & $71.93 \pm 3.78 \mathrm{a}$ & $4.54 \pm 0.21 \mathrm{a}$ & $2.57 \pm 0.21 \mathrm{a}$ & $0.41 \pm 0.02 \mathrm{a}$ & 0.16 \\
\hline
\end{tabular}

Different lowercase letters in the same column indicate significant difference $(P<0.05)$.

\subsection{Effects of soil application of hyperaccumulator plant straw on Cd content in lettuce}

Application of $S$. nigrum straw, B. pilosa straw and $G$. parviflora straw promoted the accumulation of $\mathrm{Cd}$ in the shoot parts of lettuce, $\mathrm{Cd}$ content in lettuce shoot increased by $4.46 \%(\mathrm{P}<0.05), 1.20 \%(\mathrm{P}<0.05)$ and $0.63 \%(\mathrm{P}<0.05)$ compared with the control, respectively
(Table 2). The application of hyperaccumulator plant straw significantly reduced the $\mathrm{Cd}$ content in lettuce root. The order of Cd content in lettuce root was from high to low: no straw $>S$. nigrum straw $>$ G. parviflora straw $>B$. pilosa straw. Cd content in root of lettuce treated with $S$. nigrum straw, B. pilosa straw and $G$. parviflora straw decreased by $28.19 \%(\mathrm{P}<0.05), 32.70 \%(\mathrm{P}<0.05)$ and $28.62 \%(\mathrm{P}<0.05)$ respectively, compared with the control. Cd transport coefficient of lettuce was increased by applying hyperaccumulator plant straw, and the highest was applied with $B$. pilosa straw.

Table 2 Effects of hyperaccumulate plant straw on the content of lettuce

\begin{tabular}{cccc}
\hline Plant straw & $\begin{array}{c}\text { Shoot Cd content } \\
(\mu \mathrm{g} / \mathrm{g} D W)\end{array}$ & $\begin{array}{c}\text { Root Cd content } \\
(\mu \mathrm{g} / \mathrm{g} D W)\end{array}$ & Transport coefficient \\
\hline No straw & $32.53 \pm 0.52 \mathrm{c}$ & $91.28 \pm 1.06 \mathrm{a}$ & 0.36 \\
S. nigrum straw & $33.98 \pm 0.01 \mathrm{a}$ & $65.55 \pm 0.57 \mathrm{~b}$ & 0.52 \\
B. pilosa straw & $32.92 \pm 0.33 \mathrm{~b}$ & $61.43 \pm 0.74 \mathrm{~d}$ & 0.54 \\
G. parviflora straw & $33.71 \pm 0.40 \mathrm{a}$ & $65.16 \pm 0.41 \mathrm{c}$ & 0.52 \\
\hline
\end{tabular}


Different lowercase letters in the same column indicate significant difference $(P<0.05)$.

\section{Conclusion}

Application of hyperaccumulator plants in soil ( $S$. nigrum, B. pilosa and G. parviflora) increased the shoot and root biomass of lettuce, and increased the $\mathrm{Cd}$ content and $\mathrm{Cd}$ transport coefficient of lettuce shoot. So under the condition of $\mathrm{Cd}$ pollution, three kinds of hyperaccumulator plants straw were applied ( $S$. nigrum straw, B. pilosa straw and $G$. parviflora straw) it is conducive to the normal growth of lettuce, but not conducive to safe production.

\section{References}

1. Meng, J., Cao, Y., Yao, Y., Wang, J. (2013) Research progress on the effects of straw returning on soil physicochemical and biological characters. Northern Horticulture, 11:184-186.

2. Mu, P., Zhang E.H., Wang, H.N., Fang, Y.F. (2011) Effects of straw returning on soil physical and chemical properties and microbial biomass in maize tillage layer for many years. Journal of Soil and Water Conservation, 25(5):81-85.

3. Yazdia, M., Kolahib, M., Mohajel Kazemic, E., Goldson Barnabyd, A. (2019) Study of the contamination rate and change in growth features of lettuce (Lactuca sativa Linn.) in response to cadmium and a survey of its phytochelatin synthase gene. Ecotoxicology and Environmental Safety, 180:295-308.

4. Jo-Anne, E. Cavanagh, Yi, Z., Gray, C.W., Munir, K., Lehto, N., Robinsona, B.H. (2019) Cadmium uptake by onions, lettuce and spinach in New Zealand: Implications for management to meet regulatory limits. Science of the Total Environment, 668:780-789.

5. Hirpassaa, W. D., Codling, Eton E. (2019) Growth and Metal Uptake of Lettuce [Lactuca sativa L.] on Soil Amended with Biosolids and Gypsum. Communications in Soil Science and Plant Analysis, 50:16, 2033-2040.

6. Lin, L., Liu, Q., Shi, J., Sun, J., Liao, M., Mei, L. (2014) Intercropping different varieties of radish can increase cadmium accumulation in radish. Environmental Toxicology and Chemistry, 33(9): 1950-1955.

7. Kuliková, Z. L., Lu, A. (2010) Silicon influence on maize, Zea mays L., hybrids exposed to cadmium treatment. Bulletin of environmental contamination and toxicology, 85(3): 243-250.

8. Rastmanesh, F., Moore, F., Keshavarzi, B. (2010) Speciation and phytoavailability of heavy metals in contaminated soils in Sarcheshmeh area, Kerman Province, Iran. Bulletin of environmental contamination and toxicology, 85(5): 515-519. 